\title{
A PRELIMINARY INVESTIGATION ON THE GASTROINTESTINAL HELMINTHS OF THE BARBADOS GREEN MONKEY, Cercopithecus aethiops sabaeus
}

\author{
Alex MUTANI, Kamara RHYND \& Gabriel BROWN
}

\begin{abstract}
SUMMARY
Faecal samples were collected from fifty three freshly captured monkeys which were kept at the Barbados Primate Research Centre and Wildlife Reserve (BPRCWR). Examination of these samples for gastrointestinal helminths using the zinc sulphate floatation method revealed an overall infection rate of $88.7 \%$. The parasites observed included Strongyloides (62.4\%), Physaloptera (58.5\%), Trichuris (52.8\%), Hookworm (34.0\%), Oesophagostomum (30.2\%), Trichostrongylus (3.8\%) and Ascaris (5.7\%). No significant differences in overall prevalence were observed according to sex or age. Polyparasitism appeared to be common as it was observed in $92.5 \%$ of all monkeys examined. It is concluded that these monkeys could act as reservoirs of some of the parasites which can infect man.
\end{abstract}

KEYWORDS: Cercopithecus gastrointestinal helminths; Barbados.

\section{INTRODUCTION}

Non-human primates are often valuable in studies of either human diseases processes or vaccine and drug development. It is therefore important that animals used in such studies should not harbour parasites since results obtained using parasitized animals may not reveal the true picture. Additionally, these animals play an important role in natural ecosystems, hence heavy parasite loads may have a negative impact on their population sizes.

Natural infections of gastrointestinal protozoa and helminths have been demonstrated in baboons ${ }^{3,10}$, mountain gorillas ${ }^{13,14}$, chimpanzees $^{8,10}$, and several species of monkeys ${ }^{17}$. Several studies have demonstrated that non-human primates may be carriers of human gastrointestinal parasites $^{6}$, ectoparasites ${ }^{5}$ and bacteria ${ }^{12}$; so that people living in close proximity of such animals or individuals working in game parks, animal orphanages or research stations may be at risk of acquiring pathogens from infected animals.

The African green monkey, Cercopithecus aethiops sabaeus reached the Caribbean from West Africa in the mid-17 century ${ }^{2}$. In Barbados $\left(13^{\circ} 10^{\prime} \mathrm{N}\right.$ and $\left.59^{\circ} 33^{\prime} \mathrm{S}\right)$ they are the only non-human primates, with an estimated population of about 14000 . Their greatest numbers are found in the wooded gullies in the central wetter areas, although they can also be found in plantations and gardens throughout the island ${ }^{2}$. Since they are regarded as pests, the Barbados Primate Research Center and Wildlife Reserve (BPRCWR) has developed a research and management programme to control their numbers in the wild.
The Barbados Monkey Crop Damage Control programme was started in 1979, and farmers are paid for each live, humanely trapped animal ${ }^{4}$. The trapped animals are then transported to the BPRCWR for processing. After processing they may either be exported to other laboratories abroad or kept for longer periods of time. This study was carried out to investigate the gastrointestinal helminths of these monkeys prior to processing.

\section{MATERIALS AND METHODS}

The monkeys were brought to the BPRCWR and kept in cages. Faecal samples were taken from the bottom of each cage and placed in a labelled cup. Additional information such as age, weight and sex of each animal was taken. The faecal samples were analysed by the floatation method using 33\% zinc sulphate solution. Parasite identification was based on upon the size and appearance of ova.

\section{RESULTS}

The overall prevalence of all parasites detected was $88.7 \%$. The infection rate in males $(88.9 \%$ ) was not significantly different from those in females $(88.6 \%)$. Additionally, the prevalence in adults $(88.2 \%)$ was not significantly different from that in juveniles $(88.9 \%)$. The different parasites detected included Strongyloides $(64.2 \%)$, Physaloptera $(58.5 \%)$, Trichuris (52.8\%), Hookworm (34.0\%), Oesophagostomum (30.2\%), Trichostrongylus $(3.8 \%)$ and Ascaris (5.7\%). Table 1 shows the prevalence of different parasites according to sex and age of the monkeys. In females the most prevalent parasites were Strongyloides, Physaloptera, Hookworm, Oesophagostomum and Trichuris. The differences in 
infection rates of these parasites between adults and juveniles were not significant. The situation in male monkeys was more or less similar to that in females except that only Strongyloides, Physaloptera, Hookworm and Oesophagostomum were most prevalent. It should be noted that only three male adults were available. Table 2 shows that only $7.5 \%$ of the monkeys examined had no parasites while $34.0 \%$ had between one and two parasite species. The majority of monkeys (58.5\%) harboured at least three parasite species.

\section{DISCUSSION}

The results of this study show an overall infection rate of $88.7 \%$ for all helminths. NASHER ${ }^{11}$ showed that $39 \%$ of the Arabian sacred baboon (Papio hamadryas arabicus) in Saudi Arabia was infested with various gastrointestinal helminths. In a study by KARERE \& MUNENE ${ }^{6}$, it was found that $7.7 \%$ of the De Brazzas monkeys (Cercopithecus neglectus) in Kenya had various helminth parasites. STUART et al. ${ }^{16}$ showed that in Guanacaste Province, Costa Rica, $48 \%$ of all howling monkeys (Alouatta palliata) examined had various intestinal parasitic infections. It would therefore appear that the prevalence of helminth infections would vary according to locality.

The helminths observed in this study are in agreement with SOULSBY ${ }^{17}$ who lists two species of Strongyloides (S. stercoralis and S. fulleborni), two species of hookworm (Ancylostoma duodenale and Necator americanus), three species of Oesophagostomum (O. acculeatum, $O$. bifurcatum and $O$. stephanostomum), five species of Trichostrongylus (T. colubriformis, T. vitrinus, T. probolurus, T. axei and T. orientalis) two species of Ascaris (A. lumbricoides and A. suum) and one species of Trichuris (T. trichiura) all infecting non-human primates. In the present study the helminths were not identified to species level. Usually this is done by examination of adult worms recovered from necropsy material. In this study the monkeys were not euthanised.

Physaloptera is a stomach parasite of the cat and other wild felidae. SOULSBY ${ }^{17}$ describes several species of this parasite including $P$. rara in the USA, $P$. canis in South Africa and P. pseudopraeputialis in the Philippines and USA. P. tumefascianis and P. dilitata have been found

Table 1

Prevalence of different parasite species according to sex and age group of monkeys

\begin{tabular}{|c|c|c|c|c|c|c|c|c|}
\hline \multirow{2}{*}{$\begin{array}{l}\text { Overall } \\
\text { prevalence } \\
\text { by } \operatorname{sex}^{1}\end{array}$} & \multirow{2}{*}{$\begin{array}{c}\text { Overall } \\
\text { prevalence } \\
\text { in each } \\
\text { age group }{ }^{2}\end{array}$} & \multicolumn{7}{|c|}{$\%$ Infected with ${ }^{3}$} \\
\hline & & Strongyloides & Physaloptera & Hookworm & Oesophagostomum & Trichuris & Ascaris & Tricholtrongylus \\
\hline \multirow{3}{*}{$\begin{array}{l}\text { Females } \\
88.6(35)\end{array}$} & Adult & $62.4(10)$ & $43.8(7)$ & $25.0(4)$ & $43.8(7)$ & $50.0(8)$ & $18.7(3)$ & $6.3(1)$ \\
\hline & $81.3(16)$ & & & & & & & \\
\hline & $\begin{array}{c}\text { Juveniles } \\
100.0(19)\end{array}$ & 73.7 (14) & $63.2(12)$ & $42.1(8)$ & $26.3(5)$ & $63.2(12)$ & 0 & 0 \\
\hline \multirow{4}{*}{$\begin{array}{l}\text { Males } \\
88.9 \text { (18) }\end{array}$} & Adult & $100(3)$ & $100(3)$ & $33.3(1)$ & $33.3(1)$ & $33.3(1)$ & 0 & 0 \\
\hline & $100.0(3)$ & & & & & & & \\
\hline & $\begin{array}{l}\text { Juveniles } \\
86.2(15)\end{array}$ & $46.7(7)$ & $60.0(9)$ & $33.3(5)$ & $20.0(3)$ & $46.7(7)$ & 0 & $6.7(1)$ \\
\hline & $\begin{array}{c}\text { Parasite } \\
\text { prevalence }\end{array}$ & $64.2(34)$ & $58.5(31)$ & $34.0(18)$ & $30.2(16)$ & $52.8(28)$ & $5.7(3)$ & $3.8(2)$ \\
\hline
\end{tabular}

\footnotetext{
${ }^{1,2}$ Numbers in parentheses indicate total number of animals examined; ${ }^{3}$ Numbers in parentheses indicate positive animals for each parasite.
}

Table 2

Prevalence of polyparasitism according to sex and age group of monkeys

\begin{tabular}{|c|c|c|c|c|c|}
\hline & & \multicolumn{4}{|c|}{$\%$ Infected with ${ }^{2}:$} \\
\hline & & No parasite & $1-2$ Parasite spp. & $3-4$ Parasite spp. & $>^{4}$ Parasite spp. \\
\hline \multirow[t]{2}{*}{ Females $^{1}$} & Adults (16) & $12.5(2)$ & $18.8(3)$ & $37.5(6)$ & $31.3(5)$ \\
\hline & Juveniles (19) & 0.0 & $42.1(8)$ & $15.8(3)$ & $42.1(8)$ \\
\hline \multirow[t]{3}{*}{ Males $^{1}$} & Adults (3) & 0.0 & $33.3(1)$ & $66.6(2)$ & 0 \\
\hline & Juveniles (15 & $13.3(2)$ & $40.0(6)$ & $33.3(5)$ & $13.3(2)$ \\
\hline & Total $^{2}$ & $7.5(4)$ & $34.0(18)$ & 30.7 (16) & $28.3(15)$ \\
\hline
\end{tabular}

${ }^{1}$ Numbers in parentheses indicate total number of animals examined; ${ }^{2}$ Numbers in parentheses indicate positive animals for each category. 
infecting simian primates in Africa and South America while P. caucasia and $P$. poikilometra have been demonstrated in simian primates in south east Europe, south west Asia and Africa ${ }^{17}$. There are no records of human infection with this parasite.

This study has also shown that there were no significant differences in infection rates between male and female monkeys. This is not surprising considering the possibility that all monkeys under the study would possibly have come from either the same or sympatric troupes. In their study of parasites of Cercopithecus neglectus in Kenya, KARERE \& MUNENE $^{6}$ noted that infections with Strongyloides were higher in female adults than in juveniles. Our results show that although the differences are not significantly different, female juveniles appear to have higher infection rates than adult females.

Our results also show that we did not observe any helminths in $7.5 \%$ of all monkeys examined. Whether this was due to the presence of extremely low worm burdens and therefore low egg output, or these monkeys were actually parasite-free could not be ascertained as the animals were not euthanised. What is interesting to note however, is that $58.5 \%$ of all monkeys examined had at least three parasite species, and only $34.0 \%$ had between one and two parasite species. This suggests that there is a fairly high rate of transmission of the parasites observed between individuals either because of the monkeys' gregarious nature or because of suitable environmental conditions.

With the exception of Physaloptera, all parasites observed in the present investigation are capable of infecting $\operatorname{man}^{6,9}$. It would therefore be reasonable to assume that the monkeys observed under this study would in nature act as reservoirs on human gastrointestinal helminths.

\section{RESUMO}

\section{Investigação preliminar sobre os helmintos gastrointestinais do macaco verde de Barbados, Cercopithecus aethiops sabaeus}

Amostras fecais foram coletadas de 53 macacos recentemente capturados que foram mantidos no "Barbados Primate Research Centre and Wildlife Reserve (BPRCWR)". Exames destas amostras para helmintos gastrointestinais usando o método de flutuação de sulfato de zinco revelaram média total de infecção de $88,7 \%$. Os parasitos observados incluiam Strongyloides (62,4\%), Physaloptera $(58,5 \%)$, Trichuris $(52,8 \%)$, Ancilostomídeos $(34,0 \%)$, Oesophagostomum (30,2\%), Trichostrongylus (3,8\%) e Ascaris (5,7\%). Nenhuma diferença significativa na prevalência total foi observada de acordo com o sexo e idade. Poliparasitismo parece ser comum conforme foi observado em $92,5 \%$ de todos macacos examinados. Os autores concluem que estes macacos poderiam agir como reservatórios de alguns parasitos que podem infectar o homem.

\section{ACKNOWLEDGEMENTS}

We would like to thank the Director of the Barbados Primate Research Centre and Wildlife Reserve for assistance during the entire study, Mr. Carlisle Sutton for his technical assistance and Dr. Steve St. John of the Barbados Diagnostic Laboratory.

\section{REFERENCES}

1. APPLETON, C.C. \& BOINSKI, S. - A preliminary parasitological analysis of faecal samples from a wild population of Costa Rican squirrel monkeys (Saimiri oerstedi). J. med. Primat., 20: 402-403, 1991.

2. BAULU, J.; EVERARD, C.O.R. \& EVERARD, J.D. - The African green monkey (Cercopithecus aethiops sabaeus) as a carrier of diseases in Barbados. Lab. Primate Newsletter, 26(2), 1987.

3. GHANDOUR, A.M.; ZAHID, N.Z.; BANAJA, A.A.; KAMAL, K.B. \& BOUQ, A.I. Zoonotic intestinal parasites of hamadryas baboons, Papio hamadryas, in the western and northern regions of Saudi Arabia. J. trop. Med. Hyg., 98: 431-439, 1995.

4. HORROCK, J. \& BAULU, J. - Effects of trapping on the vervet (Cercopithecus aethiops sabaeus) population in Barbados. Amer. J. Primat., 15: 223-233, 1988.

5. KALEMA-ZIKUSOKA, G.; KOCK, R.A. \& MacFIE, E.J. - Scabies in free-ranging mountain gorillas (Gorilla beringei beringei) in Bwindi impenetrable national park, Uganda. Vet. Rec., 150: 12-15, 2002.

6. KARERE, G.M. \& MUNENE, E. - Some gastrointestinal tract parasites in the wild De Brazza's monkeys (Cercopithecus neglectus) in Kenya. Vet. Parasit., 110: 153-157, 2002.

7. KESSLER, M.J.; YARBROUGH, B.; RAWLINS, R.G. \& BERARD, J. - Intestinal parasites of the free-ranging Cayo Santiago rhesus monkeys (Macaca mulatta). J. med. Primat., 13: 57-66, 1984

8. LANDSOUD-SOUKATE, J.; TUTIN, C.E. \& FERNANDEZ, M. - Intestinal parasites of sympatric gorillas and chimpanzees in Lope Reserve, Gabon. Ann. trop. Med. Parasit., 89: 73-79, 1995.

9. MURIUKI, S.M.; MURUGU, R.K.; MUNENE, E.; KARERE, G.M. \& CHAI, D.C. Some gastro-intestinal parasites of zoonotic (public health) importance commonly observed in old world non-human primates, in Kenya. Acta trop. (Basel), 71: 73-82, 1998

10. MURRAY, S.; STEM, C.; BOUdREAU, B. \& GOODALL, J. - Intestinal parasites of baboons (Papio cynocephalus anubis) and chimpanzees (Pan troglodytes) in Gombe national park. J. Zoo Wildlife Med., 31: 176-178, 2000.

11. NASHER, A.K. - Zoonotic parasite infections of the Arabian sacred baboon, Papio hamadryas arabicus Thomas, in the Asir Province, Saud Arabia. Ann. Parasit. hum. comp., 63: 448-454, 1988.

12. NIZEYI, J.B.; INNOCENT, R.B.; ERUME, J. et al. - Campylobacteriosis, salmonellosis and shigellosis in the free-ranging human-habituated mountain gorillas of Uganda. J.Wildlife Dis., 37: 239-244, 2001.

13. NIZEYI, J.B.; MWEBE, R.; NANTEZA, A. et al. - Cryptosporidium sp. and Giardia sp. infections in mountain gorillas (Gorilla gorilla beringei) of the Bwindi impenetrable national park, Uganda. J. Parasit., 85: 1084-1088, 1999.

14. NIZEYI, J.B.; SEBUNYA, D.; DASILVA, A.J. et al. - Cryptosporidiosis in people sharing habitats with free-ranging mountain gorillas (Gorilla gorilla beringei), Uganda. Amer. J. trop. Med. Hyg., 66: 442-444, 2002.

15. OGUNJI, F.O.; AKINBOADE, O.A.; DIPEOLU, O.O.; AYENI, J. \& OKAEME, A. The prevalence of gastrointestinal parasites and bacteria in the game scouts at the Kainji Lake National Park of Nigeria. Int. J. Zoonoses, 11: 119-122, 1984.

16. STUART, M.D.; GREENSPAN, L.L.; GLANDER, K.E. \& CLARKE, M.R. - A coprological survey of parasites of wild mantled howling monkeys, Alouatta palliata palliata. J. Wildlife Dis., 26: 547-549, 1990.

17. SOULSBY, E.J.L. - Helminths, Arthropods and Protozoa of domesticated animals. 7. ed.. London, ELBS, 1982.

Received: 24 April 2003

Accepted: 11 August 2003 